\title{
Assessment of Present Status and Future Needs of Four Coral Reef Sites Along the Gulf of Aqaba, Egypt
}

\author{
Mohammed Shokry Ahmed Ammar*
}

National Institute of Oceanography and Fisheries Suez, P.O. Box 182, Egypt

\begin{abstract}
The present status and future needs of four coral reef sites (Taba, Nuweiba, Dahab and Sharm El-Sheikh) along the Gulf of Aqaba, Egypt were evaluated. A total of 60 quadrats, distributed at different depths or different patches were surveyed at each site during the year 2007. Three mooring buoys were reported only in Ras Umm Seid but nothing was found in other sites, however excessive boating and diving pressure were recorded only in Ras Umm Seid. Highest amount of garbage was recorded in Nuweiba, patrolling efficiency was best in Taba but no patrolling activities were recorded in other sites. Ras Umm Seid (Sharm El-Sheikh) had the highest amount of dead corals (13\%) due to increased boating and diving pressure compared to other sites, however Dahab had the lowest amount of dead corals (4\%) due to the rough conditions (strong wind and waves) causing difficulties in accessing that site. Nuweiba and Taba had high percent cover of sands (10\% and $11 \%$, respectively) playing a key role in the considerable amount of dead corals in both sites. Lowest \% new coral recruits in Taba $(0.5 \%)$ was associated with the soft sandy bottom, the opposite was true in Sharm El Sheikh due to the rocky bottom. Future needs of the studied sites include decreasing the number of divers to the diver carrying capacity (DCC), repair of existing buoys and incorporation of 5 more buoys in Ras Umm Seid. Other sites have no future needs in these regards as they are far beyond the DCC. Nuweiba needs first of all to be cleaned, then being protected for giving the chance of recovery. Except for Taba which has efficient patrolling, the other 3 sites need efficient terrestrial and marine patrolling as well as enforcement of EEAA regulations. However reef access points which were absent in all sites need to be established to minimize reef damage on accessing deeper water. Also, the environmental awareness field signs which were absent in all sites need to be established and managed. Taba is recommended as a protected area as it has the food for threatened species beside being useful as a nesting site. Ras Umm Seid is recommended to have a established artificial reef to draw the attention of divers and snorklers from the natural reefs and prepare artificial shelters for fishes thus promoting the fish resources.
\end{abstract}

\section{INTRODUCTION}

Coral reefs of South Sinai are among the most important reef communities all over the world. Moreover, they are ecosystems providing shelters for a big variety of fishes and so many other organisms, including urchins, cucumbers, molluscs, as well as other benthos, forming together what the scientist call the underwater forest. Coral reefs are very important as they are a source of a big quantity of protein, besides, many of them have medical and scientific value [1]. Some reef forms, the fringing reef, protect the shore from being eroded [2].

These very important corals are strictly sensitive to the hydrodynamic action of water, which might be increased by boats and divers [3], as well as to the water quality [4], this quality is affected by some factors, like temperature, salinity, dissolved oxygen, nutrients as well as pollution [5-7].

Previous studies assured a negative correlation between the number of divers, especially the unexperienced divers and the amount of coral reef damage [8]. Number of boats are also effective by leakage of petroleum oil which is toxic

*Address correspondence to this author at the National Institute of Oceanography and Fisheries, Suez, P.O. Box 182, Egypt; Tel: (Inst.) 002062 3360015; Fax: (Inst.) 002062 3360016; Mobile: 002010 2660980; E-mail: shokey_1@yahoo.com and harmful to coral communities or by causing audio and hydrodynamical disturbance to the coral reef communities which is naturally a calm and sensitive ecosystem or by inputing the divers and snorklers who might be unexperienced representing a possible harm to the reef [9]. Divers may damage reefs by trampling, walking, collection or accidental damage by inexperienced divers.

Present tourism in South Sinai is predominantly concentrated on the coast from Sharm El Sheikh to Nabq where more than $70 \%$ of the hotel rooms are located receiving more than $90 \%$ of the tourist visitors (source: city council). The area will probably also be the main magnet for tourism in the future due to the location of the international airport and the international branding of the name Sharm El-Sheikh. While diving and snorkeling are listed as the major pull factors for visitors to South Sinai, it should be noted that $48 \%$ of visitors to dive locations are non-divers; snorklling, swimming, or viewing reefs from glass bottom boats, or just on pleasure lunch excursions (mainly domestic visitors) (source: city council, dive guides). Other visitors to dive sites are SCUBA divers engaging in a wide range of dive experiences (source: city council, dive guides):

- Daily diving - two dives during the day (78\%)

- Night diving - one dive at night $(6 \%$, predominantly experienced divers) 


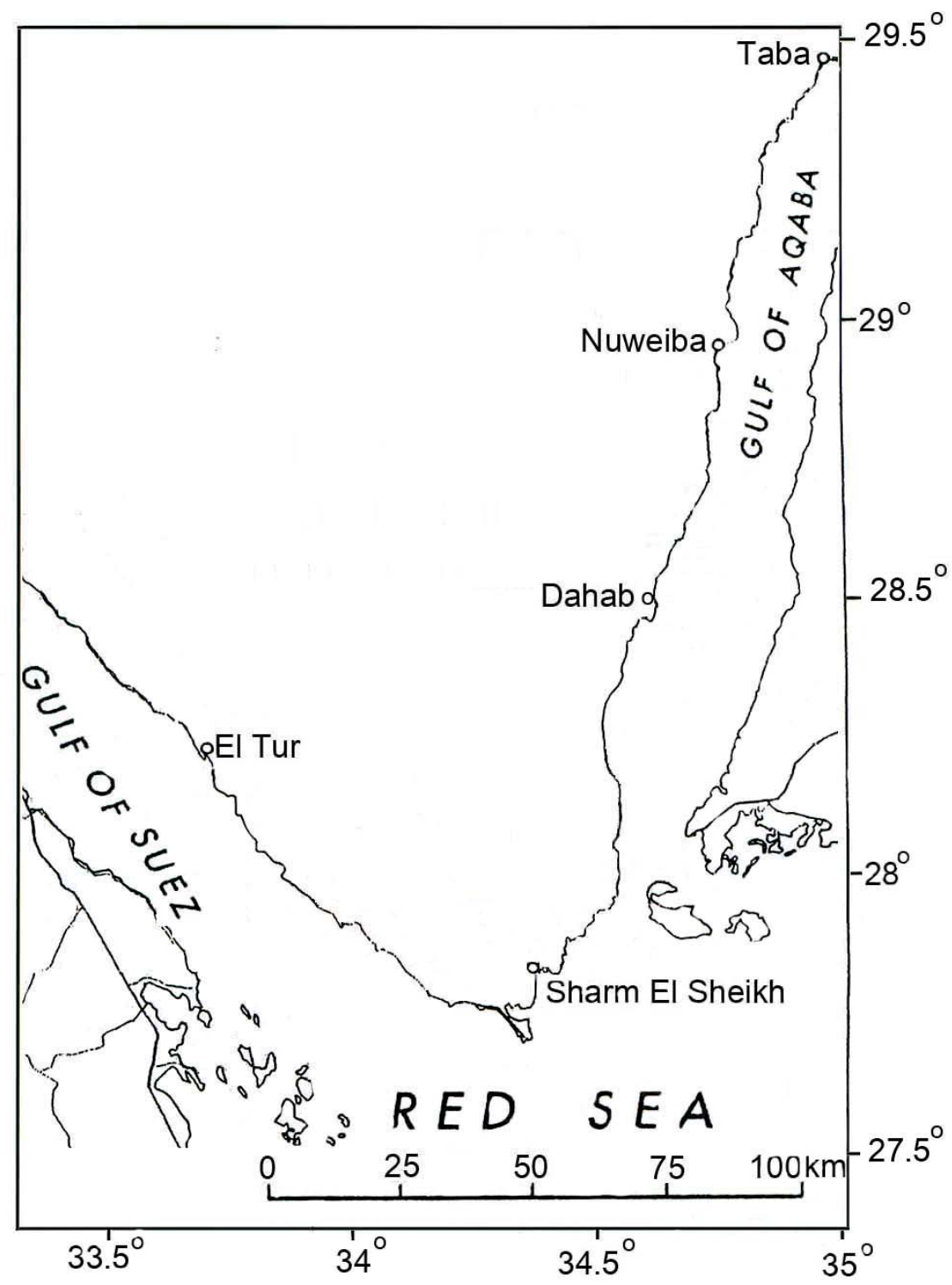

Fig. (1). Location map of the study sites.

- Diving safari excursions - normally 5-6 days $(16 \%)$

Reef mooring systems are needed for the protection of reefs. Reef mooring systems in South Sinai, for use by excursion vessels, were first installed in 1994, mainly funded by the EC (European Commission), and were maintained with EC funding up to 2002 after which maintenance costs were covered by the EEAA (Egyptian Environmental Affairs Agency). However, only a third of moorings are presently in functional condition as dimensioning was aimed at far smaller vessels.

There is presently no tourism management plan for the Gulf of Aqaba/Ras Mohammed. An outline environmental plan was produced in 2003 by the Regional Organisation for the Conservation of the Red Sea and the Gulf of Aden (PERSGA), National Parks of Egypt and the EEAA.

Recreational diving can damage reefs both directly and indirectly. Several studies have looked to the adverse effect of heavy boating pressure and the provision of facilities for tourists [10-12]. Resuspension of sediments may also stress organisms [13].

Effective management of coral reefs and the people visiting or living near them can only occur through supportive policies, enhanced capacity, sustainable financing and significant on-the-ground actions that are based on appropriate information, knowledge and awareness [9].

The main goal of the study is to evaluate the present status and future needs of four coral reef communities along the Gulf of Aqaba, Egypt as it is the key element affecting sustainable development in South Sinai, Egypt.

\section{MATERIALS AND METHODS}

Four sites were chosen along the Gulf of Aqaba to study coral reefs and associated fauna and flora. These sites were Taba, Nuweiba, Dahab and Sharm El-Sheikh representing a transect along the Gulf of Aqaba (Fig. 1). Latitudes and lon- 
Table 1. Percent Cover of Different Coral Growth Forms in the Studied Sites

\begin{tabular}{|c|c|c|c|c|}
\hline & Taba & Nuweiba & Dahab & 8 \\
\hline \hline Branching Corals & 14 & 10 & 18 & 18 \\
\hline Massive Corals & 7 & 5 & 26 & 10 \\
\hline Encrusting Corals & 4 & 4 & 11 & 8 \\
\hline Soft Corals & 3 & 13 & 5 & 6 \\
\hline Hydrocorals & 2 & 4 & 5 \\
\hline
\end{tabular}

gitudes of the studied sites are as follows: Taba: $29^{\circ}$ $28.369^{\circ} \mathrm{N} 034^{\circ} 51.578^{\circ} \mathrm{E}$; Nuweiba: $28^{\circ} 59.164^{\top} \mathrm{N} 034^{\circ}$ 41.180`E; Dahab: $28^{\circ} 31.849^{`} \mathrm{~N} 034^{\circ} 30.886{ }^{\circ} \mathrm{E}$; Ras Umm Seid (Sharm El-Sheikh): $27^{\circ} 50.878^{`} \mathrm{~N} 034^{\circ} 18.956^{`} \mathrm{E}$.

A preliminary visual survey of the studied sites showed that the site at Taba lies few hundred meters to the north of Pharao's island and characterized by the shallowness and sandy bottom with abundance of algal turf, seagrasses, Turkey fish, sea anemone and molluscs while the site at Nuweiba lies just at the southern border of Domina Elaria hotel and characterized by long intertidal zone that reaches several hundered meters with abundance of algae and seagrasses, followed by the coral reef zone with abundance of the soft corals. Dahab is an open site with deep and steep reef slope with abundance of gorgonians, massive and encrusting corals as well as the presence of moray. Ras Umm Seid is characterized by a deep slope with the abundance of the soft corals and the presence of considerable amount of the yellow spots disease, molluscs, the feather star and algae. The study was performed throughout the period Spring 2007 - Winter 2007.

Using SCUBA diving and a $1 \mathrm{~m}^{2}$ quadrat with a quadrat grid, coral reef communities were assessed with respect to percent cover of live corals, dead corals, new coral recruits and coral diseases. A total of 60 quadrats, distributed at different depths or different patches were surveyed at each site. In each of the deep sites (Nueiba, Dahab and Ras Umm Seid), the 60 quadrats were distributed equally in an order of 10 quadrats at each of the depths $1 \mathrm{~m}, 5 \mathrm{~m}, 10 \mathrm{~m}, 20 \mathrm{~m}, 30 \mathrm{~m}$ and $35 \mathrm{~m}$. However, in Taba (the shallow site), the 60 quadrats were distributed equally into 6 shallow reef patches in an order of 10 quadrats per patch. Sample photos with a high resolution underwater camera beside collection of small pieces of samples were conducted to help in later identification of species.

Percent cover was estimated as follow:

(Number of grid squares overlying coral or other feature / Total number of squares)*100.

Percent cover of other living features like sea anemones, molluscs, echinoderms, sponges, sea grasses and algae in addition to the non living features like dead corals, bare rocks, rubbles and sands/sediments were also assessed in the same way. Human impacts (like number of boats, number of divers, number of snorklers, number of existing buoys, number of interlacing angle fishing threads, garbage, patrolling efficiency, presence of reef access points) on these coral reef sites were assessed during the survey. In addition future needs depending on the status and impact on each site were provided.

\section{RESULTS}

The percent cover of different coral growth forms at the studied sites is shown in Table 1. The highest percent cover $(18 \%)$ of branching corals was found in Ras Umm Seid while that of massive and encrusting corals reached its maximum (18\% and $26 \%$, respectively at Dahab. Soft corals attained a maximum (13\%) at Nuweiba whereas hydrocorals were found having a maximum percent cover of 6 at Ras Umm Seid.

Abundant coral species and their percent cover at the four studied sites are shown in Table $\mathbf{2}$. Six abundant corals were recorded in each site. In site 1 (Taba) Asteriopora myriophthalma, Acropora eurystoma, Lobophyllia corymbosa, Pocillopora damicornis, Millopora dichotoma and Acropora tenuis have a total percent cover of 13.5 compared to 16.5 for other corals. In this site, the branching coral Acropora eurystoma and the massive coral Asteriopora myriophthalma recorded the highest percent cover, each representing 3\% cover. In site 2 (Nuweiba), Lithophyton sp., Acropora hemperichi, Acropora humilis, Goniastrea retiformis, Echinopora lamellosa and Turbinaria mesentrina were found having a total percent cover of 20.5 compared to 15.5 percent cover for other corals. The soft coral Lithophyton sp. and the branching stony coral Acropora hemperichi were the most abundant corals in this site having 8 and 4 percent cover, respectively. Site 3 (Dahab) was characterized by Pachyseris rugosa, Oxypora lacera, Mycedium elephantotus, Pavona varianns, Porites lobata and Siphonogorgonian sp. having a total percent cover of 29 compared to 39 percent cover for other corals. The encrusting coral Pachyseris rugosa and the gorgonian soft coral Siphonogorgonian sp. were the most abundant coral in this site having 7 and 6 percent cover respectively. Corals of site 4 (Ras Um Seid) included Xenia sp., Acropora hemperichi, Porites lobata and Acropora eurystoma having percent cover of 29 compared to 39 percent cover for other corals. The soft coral Xenia sp. and the branching stony coral Acropora hemperichi were the most abundant coral species in this site having 6 and 5 percent cover, respectively.

The percent cover of other living organisms at the studied sites is shown in Table 3 . The percent cover of the bivalve Tridacna sp. attained a maximum of 3 at Taba, Dahab and Ras Umm Seid and totally absent in Nuweiba. Contrary to 
Table 2. Abundant Coral Species and their Percent Cover at the Studied Sites

\begin{tabular}{|c|c|c|c|}
\hline Sites & Corals Species & Percent Cover & $\begin{array}{l}\text { Depth of Most Dominant Species (m) in Sites 2-4 / Number of } \\
\text { Patches Having Dominant Species in Site } 1\end{array}$ \\
\hline $\begin{array}{l}\text { Site } 1 \\
\text { (Taba) }\end{array}$ & $\begin{array}{c}\text { Asteriopora myriophthalma } \\
\text { Acropora eurystoma } \\
\text { Lobophyllia corymbosa } \\
\text { Pocillopora damicornis } \\
\text { Millepora dichotoma } \\
\text { Acropora tenuis } \\
\text { Other corals } \\
\text { Total }\end{array}$ & $\begin{array}{c}3 \\
3 \\
2.5 \\
2 \\
1.5 \\
1.5 \\
16.5 \\
30\end{array}$ & $\begin{array}{l}5 \text { patches } \\
4 \text { patches } \\
2 \text { patches } \\
3 \text { patches } \\
2 \text { patches } \\
4 \text { patches } \\
6 \text { patches }\end{array}$ \\
\hline $\begin{array}{c}\text { Site } 2 \\
\text { (Nuweiba) }\end{array}$ & $\begin{array}{l}\text { Lithophyton } \mathrm{sp} . \\
\text { Acropora hemperichi } \\
\text { Acropora humilis } \\
\text { Goniastrea retiformis } \\
\text { Echinopora lamellosa } \\
\text { Turbinaria mesentrina } \\
\text { Other corals } \\
\text { Total }\end{array}$ & $\begin{array}{c}8 \\
4 \\
3 \\
2.5 \\
1.5 \\
1.5 \\
15.5 \\
36\end{array}$ & $\begin{array}{c}10 \mathrm{~m}, 20 \mathrm{~m} \\
20 \mathrm{~m} \\
1 \mathrm{~m}, 5 \mathrm{~m} \\
20 \mathrm{~m} \\
30 \mathrm{~m} \\
35 \mathrm{~m} \\
5 \mathrm{~m}, 10 \mathrm{~m}\end{array}$ \\
\hline $\begin{array}{c}\text { Site } 3 \\
\text { (Dahab) }\end{array}$ & $\begin{array}{c}\text { Pachyseris rugosa } \\
\text { Oxypora lacera } \\
\text { Mycedium elephantotus } \\
\text { Pavona varians } \\
\text { Porites lobata } \\
\text { Siphonogorgonian sp. } \\
\text { Other corals } \\
\text { Total }\end{array}$ & $\begin{array}{l}7 \\
4 \\
3 \\
2 \\
7 \\
6 \\
39 \\
68\end{array}$ & $\begin{array}{c}35 \mathrm{~m} \\
30 \mathrm{~m} \\
30 \mathrm{~m} \\
30 \mathrm{~m}, 35 \mathrm{~m} \\
20 \mathrm{~m}, 30 \mathrm{~m} \\
10 \mathrm{~m}, 20 \mathrm{~m} \\
1 \mathrm{~m}, 5 \mathrm{~m}\end{array}$ \\
\hline $\begin{array}{c}\text { Site } 4 \\
\text { (Ras Umm Seid) }\end{array}$ & $\begin{array}{c}\text { Xenia } \text { sp. } \\
\text { Acropora hemperichi } \\
\text { Porites lutea } \\
\text { Porites compressa } \\
\text { Porites lobata } \\
\text { Acropora eurystoma } \\
\text { Other corals (mostly hydrocorals, gor- } \\
\text { gonians and branching stony corals) } \\
\text { Total }\end{array}$ & $\begin{array}{l}6 \\
5 \\
4 \\
2 \\
1 \\
3 \\
26 \\
47\end{array}$ & $\begin{array}{c}20 \mathrm{~m}, 30 \mathrm{~m}, 35 \mathrm{~m} \\
10 \mathrm{~m}, 20 \mathrm{~m} \\
30 \mathrm{~m} \\
30 \mathrm{~m} \\
35 \mathrm{~m} \\
1 \mathrm{~m}, 5 \mathrm{~m} \\
1 \mathrm{~m}, 10 \mathrm{~m}\end{array}$ \\
\hline
\end{tabular}

that, Nudibranch was only recorded in fewer number in $\mathrm{Nu}$ weiba having a maximum percent cover of 1 . Values of the percent cover of the sea urchin Diadema setosum are similar to each other for both Taba and Ras Umm Seid with a maximum value of 2, totally absent in Nuweiba and recorded $1 \%$ in Dahab. The sea urchin Prinocidaris baculosa was found only in Nuweiba and totally absent in other sites. Sea cucumbers were not recorded in Taba and Dahab. Feather star were only found in Ras Um Seid (6\%), not recorded in other sites. Sea grasses were not recorded in Dahab and Ras Umm Seid but they were recorded at Taba and Nuweiba having a maximum percent cover of 9 at each site. Algal turf was highly abundant at Taba (16\%) than Ras Umm Seid
(1\%), totally absent in Nuweiba and Dahab. Bladder blister algae were recorded only at low percent cover (3) at Ras Umm Seid. Other macroalgae were only found in Nuweiba having percent cover of 14 .

The percent cover of non living features at the studied sites is shown in Table 4 . The percent cover of dead corals and bare rocks attained a maximum of 13 and 12, respectively at Ras Umm Seid and a minimum of 4 and 7, respectively at Dahab whereas rubbles attained a maximum of 3 at Ras Umm Seid and a maximum of 1 at both Taba and Nuweiba. Sand was maximal at Taba $(11 \%)$ and attained a minimum of $1 \%$ at Ras Umm Seid. 
Table 3. Percent Cover of Other Fauna and Flora in the Studied Sites

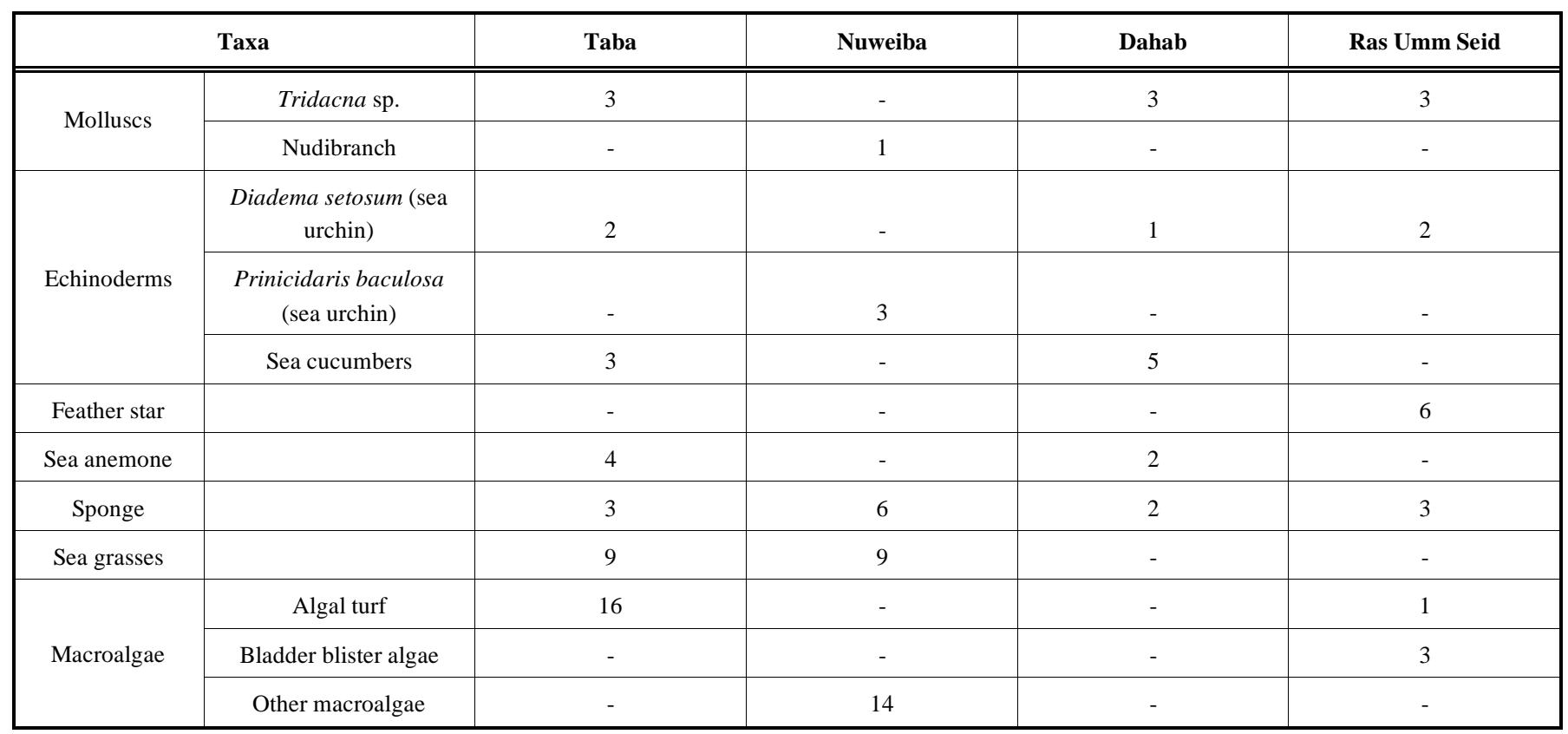

Table 4. Percent Cover of Non Living Features in the Studied Sites

\begin{tabular}{|c|c|c|c|c|}
\hline & Taba & Nuweiba & Dahab & Ras Umm Seid \\
\hline \hline Dead Corals & 9.5 & 5 & 7 & 13 \\
\hline Bare Rocks & 8 & 11 & 2 & 3 \\
\hline Rubbles & 1 & 1 & 4 & 1 \\
\hline Sand & 11 & 10 & 17 & 29 \\
\hline Total & 29.5 & 27 & & 7 \\
\hline
\end{tabular}

Table 5. Percent Cover of New Coral Recruits and Coral Diseases in the Studied Sites

\begin{tabular}{|c|c|c|c|c|}
\hline & Taba & Nuweiba & Dahab & Ras Umm Seid \\
\hline New coral recruits & 0.5 & 2 & 3 & 5 \\
\hline Coral diseases & 1 & 2 & 1 & 1 \\
\hline
\end{tabular}

The percent cover of new coral recruits and coral diseases are shown in Table 5. New coral recruits were highest in Ras Umm Seid $(5 \%)$ reached its minimum $(0.5 \%)$ at Taba. Coral diseases were maximal $(2 \%)$ at Nuweiba and reported $1 \%$ at each of other sites.

Data of human impacts are shown in Table 6. Average number of divers per day was 0,15 and 20 in Taba, Nuweiba and Dahab, respectively attaining its highest value (140) in Ras Umm Seid. Similarly, average number of snorklers was 0, 20 and 25 in Taba, Nuweiba and Dahab, respectively attaining its maximum value (100) in Ras Umm Seid. Moreover, number of diving boats was 0,2 and 3 in the same three sites, respectively having its highest value of 7 in Ras Umm Seid. Number of existing mooring buoys was 3 (with a dete- riorated status) in Ras Umm Seid and 0 in other sites. Garbages (plastic bags, chains, cans, tyres and onshore faeces) were maximum in Nuweiba and minimum in Taba. However, number of interlacing threads of angle fishing was 7, 4 and 1 in Nuweiba, Dahab and Ras Umm Seid decreased to 0 in Taba. An interlacing fishing thread in Dahab is indicated in Fig (2). No reef access points or environmental awareness signs were recorded in any of the study sites. Patrolling was efficient only in Taba and absent in other sites.

\section{DISCUSSION}

In Taba, abundant corals were represented by five branching and one massive coral, total percent cover of 
Table 6. Data of Human Impacts in the Studied Sites

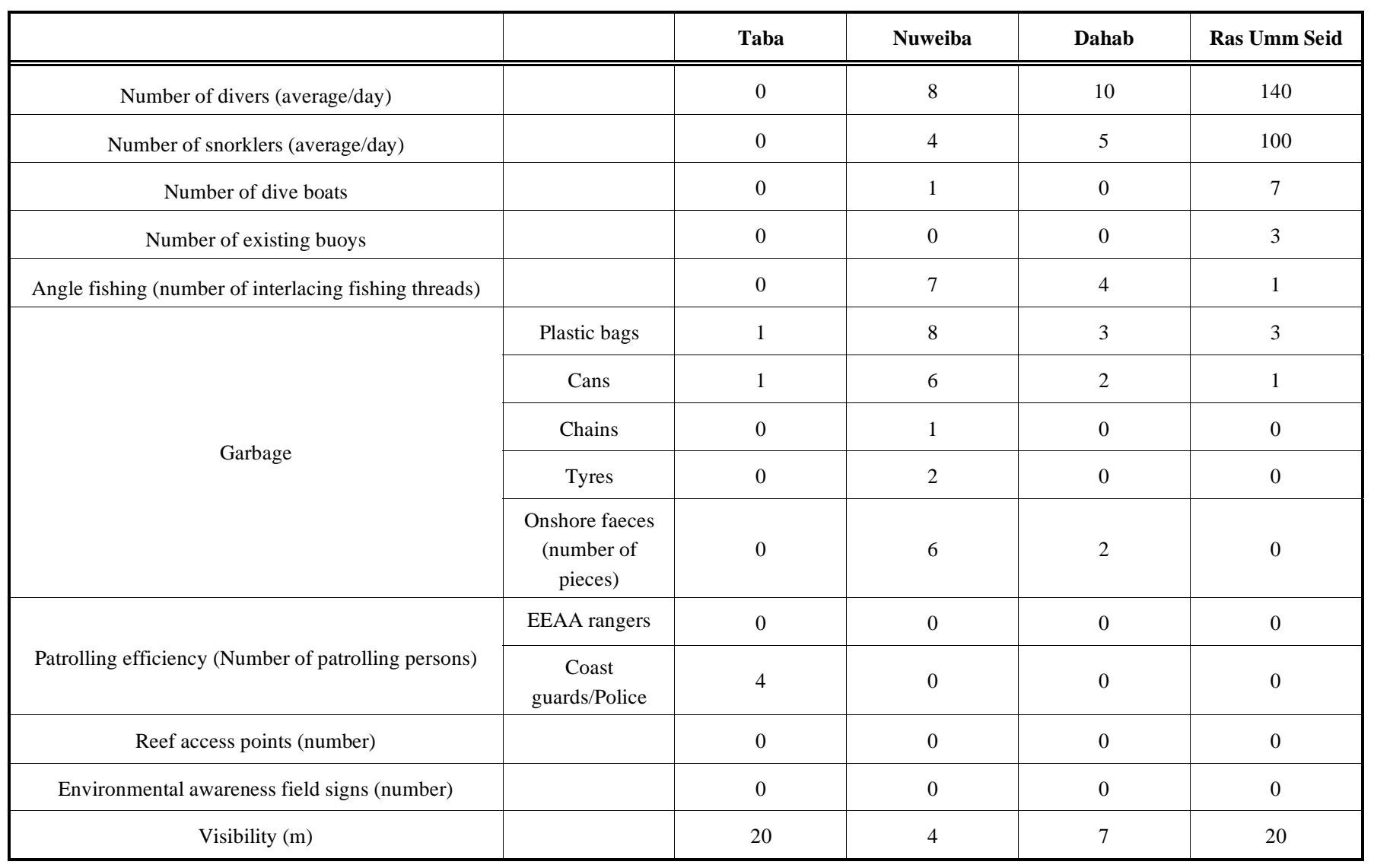

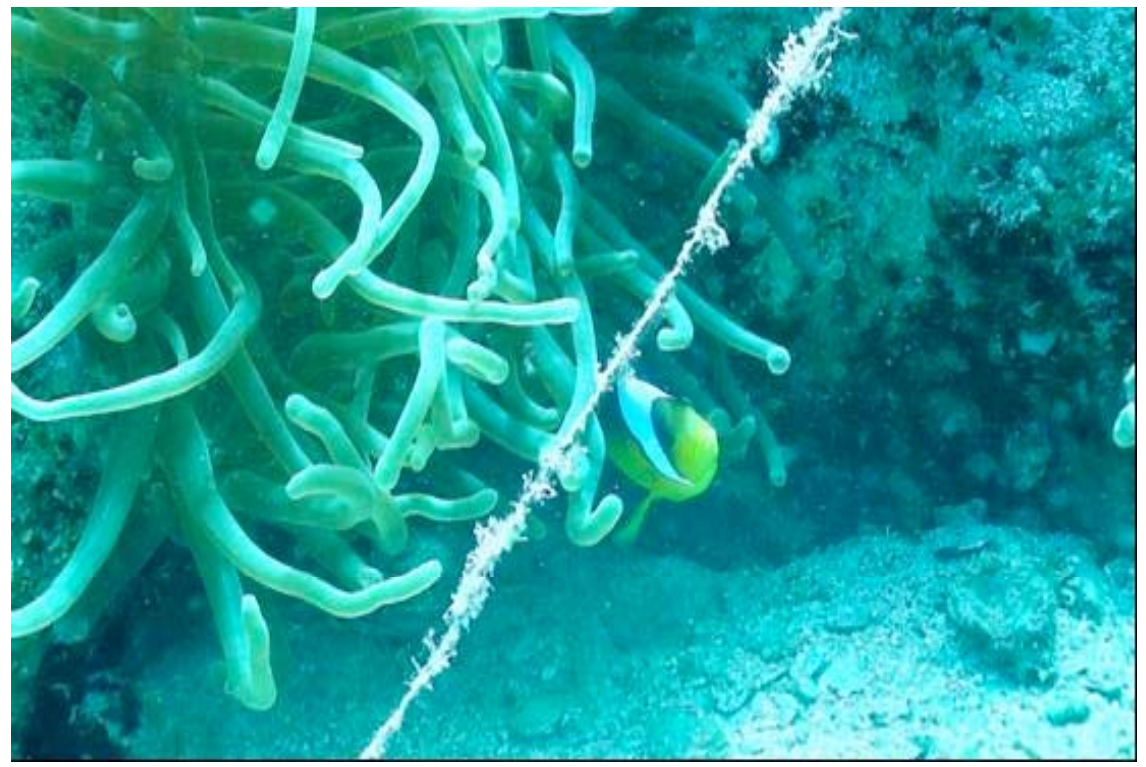

Fig. (2). Clownfish living in sea anemone at Dahab, a fishing thread is an evidence of angle fishing impact.

branching corals was also higher than other growth forms of the same site. This was due to the shallowness and high illumination at Taba (3m depth). Branched colonies usually decrease with increasing depth and are replaced by encrusting and flattened colonies which have a great ability to entrap light [14]. However, an exception was the massive coral Asteriopora myriophthalma that was also dominant in that shallow site because its corallite morphology expand, extend and deepen like those of branching corals, thus favouring the life in shallow areas. A relationship between corallite morphology and light, where the corallites expand, extend and deepen in light conditions [15]. The highest percent cover of soft corals at Nuweiba (the site impacted by highest amount of garbage and high amount of algae can be explained by the 


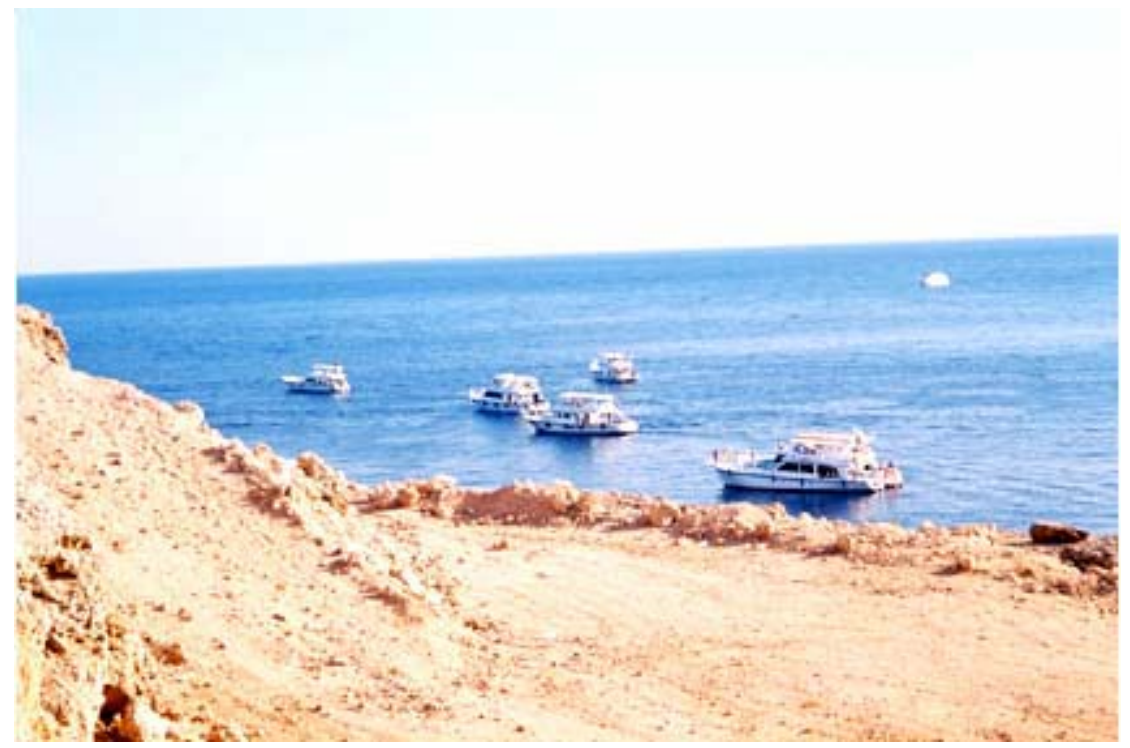

Fig. (3). Heavy boating in Ras Umm Seid, Sharm El-Sheikh.

conclusion of Ammar [16] that soft corals have a higher recovery rate and a faster recovery time than stony corals because soft corals could adapt and compete for space more faster after being subject to impacts especially physical impacts. Benayahu [17] showed that soft corals replace stony corals and cause their death, this is an important factor affecting coral recolonization [18]. Increased massive and encrusting corals than branching corals in Dahab especially in deeper areas can be explained by the wider surface areas that can entrap a larger amount of light in case of weak illumination at deeper areas and caves or at higher turbidity. The studied site in Dahab is an open site with a very steep and deep slope having a lot of caves and shadow areas which initiate a condition of weak illumination. Sheppard [19] referred to the occurrence of Porites sp. (a massive coral) in abundant cover in turbid water with weak light compared to Acropora sp. (a branching coral). On the contrary, Ras Umm Seid is a site protected from winds and waves, with a gentle slope initiating good illumination until up to $20 \mathrm{~m}$ depth, promoting the abundance of branching corals. The high percentage cover of hydrocorals especially in shallow areas at Ras Umm Seid, compared to other sites, agrees with the finding of Ammar [20] that, Millepora sp. (a hydrocoral) prefers high illumination and has a strong skeletal density to tolerate strong waves. On the contrary, the lowest amount of hydrocorals (Millepora dichotoma) in Taba is due to the soft sandy bottom with increased algae and seagrasses. However, the highest percent cover of the soft coral Xenia sp. than other species in Ras Umm Seid agrees with the result of Atrigenio and Alino [21] that, the soft coral Xenia sp. is a potent competitor and plays an important role in determining succession and community structure.

The absence of the bivalve Tridacna sp. in Nuweiba and its abundance in other sites is attributed to the highest amount of garbage (plastic bags, cans, chains, tyres and onshore faeces as well as the lowest visibility in Nuweiba compared to other sites. Hean and Cacho [22] indicated that low visibility or increased turbidity have negative effects on the clams Tridacna sp. causing them to grow poorly. Hart et al.
[23] showed that water clarity is one of the main factors affecting growth of the clam Tridacna sp. However, the presence of Nudibranch only in Nuweiba agrees with the conclusion of Barbeau et al. [24] that sea slugs preferred darkness over light, they also preferred rough substratum over smooth substratum when they are in dark. Presence of sea cucumbers only in Taba and Dahab is due to the better patrolling efficiency in both sites preventing illegal collection of cucumbers. The variations in the amount of sea urchins with the amount or kinds of algae or seagrasses in different sites is explained by the result of Carpenter [25, 26] that some control of algal abundance is affected by the grazing activity and food preference of sea urchins.

The highest amount of dead corals in Ras Umm Seid, Sharm El-Sheikh is due to the increased boating (Fig. 3) and diving pressure compared to other sites. Jameson et al. [9], in his damage assessment of some Red Sea diving sites, found that diving sites suffer, in varying degrees, from physical damage and need management attention. Coral reefs worldwide are subjected to extensive human impacts caused by snorkelers and SCUBA divers [8, 11]. Wielgus et al. [12] found that SCUBA divers are significant causes of coral partial mortality. However, the lowest amount of dead corals in Dahab is due to the rough conditions (strong wind and waves) causing difficulties in accessing that site. That result is supported by the finding of Ammar [27], in his estimation of the alarming threats to the red organ pipe coral Tubipora musica, that flourishing live Tubipora colonies were found in considerable amounts in Wadi El Mahara, because of the very strong wave breaking on the reef crest, the zone containing the Tubipora colonies, making it difficult to access for collection. The highest amount of bare rocks and rubbles in Ras Umm Seid is an evidence of the highest amount of past coral breakage compared to other sites [28]. The high percent cover of sands in both Nuweiba and Taba play a key role in the considerable amount of dead corals in both sites. This agrees with the results of Hudgoson \& Carpenter [29] and Ammar \& Mahmoud [5] that sediments plays an important role in decreasing coral distribution in the Red sea. 
Lowest recruitment rate (as indicated by the lowest percent cover of new recruits) in Taba is due to the soft sandy bottom which is weak enough to prevent stability and settlement of coral larvae while the highest recruitment rate in Ras Umm Seid is due to the rocky bottom, water clearance and being well sheltered to allow larval stability, also the damage due to divers in Ras Umm Seid may initiate recruitment (recolonization). Damage can initiate recolonization through the accumulation of small broken branches (nubbins) and the availability of substratum used for settlement and survival of those nubbins. Pearson [18] and Nezali et al. [30] showed that factors which can influence coral recolonization include the extent of damage and its location, the availability of coral larvae, the requirement for a "conditioning" period of the substratum before corals can settle, the availability and diversity of microhabitats for settlements and survival, the role of grazers, and competition with other organisms such as algae and soft corals. Highest amount of coral diseases in Nuweiba is associated with the highest amount of garbage in that site initiating bacterial diseases.

\section{FUTURE NEEDS}

Highest recorded average number of divers per day in Ras Umm Seid (140 diver/day) means that the number of divers per year is more than 51000 which is far exceeding the diver carrying capacity (DCC). From guidelines developed in 1992 by the World Tourism Organization and the UN Environment Programme, a basic equation for calculating visitor carrying capacity is:

Carrying capacity $=$ Area $u$ sed by tourists /Average individual standards

Here, the average individual standard (often measured in square meters per person) is the space a tourist requires for an acceptable experience in the protected area, which will vary depending on the area, activity, and management. Hawkins and Roberts [31] concluded that the diver carrying capacity, which is the number of dives per site per year, the site can tolerate, to be a total of 6000 dives/site/year. Therefore, one of the future needs of Ras Umm Seid site is to decrease the number of divers to the diver carrying capacity. However, no future needs for other sites in that regard is required as they are far beyond the DCC. Since Ras Umm Seid has only 3 mooring buoys which are deteriorated, repair of existing buoys and incorporation of more buoys ( 5 more buoys) is urgent especially the site can tolerate up to 8 buoys. Other sites have no future needs in these regards as they are far beyond the DCC. Since Nuweiba has the highest amount of garbage, it needs first of all to be cleaned then being protected for giving the chance of recovery. Except for Taba which has efficient patrolling, the other 3 sites need efficient terrestrial and marine patrolling as well as enforcement of EEAA regulations to stop illegal fishing or collection of marine species and to ensure compliance with EEAA regulations. However reef access points, which were absent in all sites, have to be established to minimize reef damage on accessing deeper water. Several authors [32-34] documented the degradation of coral reefs by reef walkers in the absence of reef access points. Also, the environmental awareness field signs which were absent in all sites need to be established and well managed. As the site of Taba has the bottom largely covered with seagrasses, a substarte that is useful for feeding of the threatened species like marine turtles or manta rays, beside being useful as a nesting site, it is recommended as a protected area. As the site of Ras Umm Seid has the highest boating and diving pressure, it is recommended establishing an artificial reef in that site to draw the attention of divers and snorklers from the natural reefs and prepare artificial shelters for fishes promoting the fish resources. From the review of some articles [35-41], it was concluded that artificial reefs could be potentially used for tourism SCUBA diving, recreational angling, surfing, beach enhancement, fisheries, nature conservation and science.

\section{ACKNOWLEDGEMENT}

This work is a part of the plan of the National Institute of Oceanography and Fisheries entitled "Human Impacts on the Red Sea Environments" for the year 2006-2007.

\section{REFERENCES}

[1] Ammar MSA. Goods and benefits of the coral reef ecosystem in the Red Sea, Egypt. First Scientific Workshop on: Goods and Benefits of the Ecosystems in Egypt, Academy of Scientific Research and Technology, The National Committee for Conservation of Nature and Natural Resources, Cairo 2007.

[2] Job S, Schrimm M, Morancy R. Reef Restoration: Practical Guide for Management and Decision-Making. Carex Environnement, Ministère de l'Écologie et du Développement Durable, IFRECOR 2003 ; p. 32.

[3] Ammar MSA. Impacts of recreational dives and application of a coral damage index along the Egyptian coast of the Red Seq. ACPEU Fisheries Res Report. Mombasa, Kenya, 19-22 June 2000, Brussels 2001; 10: 96-107.

[4] Ammar MSA, Mohammed TA, Mahmoud MA. Skeletal density (strength) of some corals in an actively flooding and a non flooding site south Marsa Alam, Red Sea, Egypt. J Egypt German Soc Zool 2005; 46(D): 125-39.

[5] Ammar MSA, Mahmoud MA. Effect of physico-chemical factors and human impacts on coral distribution at Tobia Kebir and Sharm El Loly, Red Sea-Egypt. Egypt J Aquatic Res 2006; 32(1): 184-97.

[6] Ammar MSA, Ghobashi AA, Omran MA, Shaaban AM. Status of coral reefs affected by different impacts in some sites of the Red Sea. Egypt J Aquatic Res 2007; 33(1): 224-37.

[7] Ammar MSA, Boumeester J, Riegl B, Hausser J, Keck A. Possible causes, consequences of changes and future of coral reefs in Dahab, Gulf of Aqaba, Red Sea, Egypt. International Conference on Aquatic Resources: Needs and Benefits, Sheraton, Alexandria, Egypt. Egypt J Aquatic Res 2007; (32): 160-79.

[8] Zakai D, Chadwic-Furman NE. Impact of intensive recreational diving on reef corals at Eilat, northern Red Sea. Biol Conserv 2002; 105: 179-87.

[9] Jameson SC, Ammar MSA, Saadalla E, Mostafa HM, Riegl B. A quantitative ecological assessment of diving sites in the Egyptian Red Sea during a periode of severe anchore damage: a baseline for restoration and sustainable tourism management. J Suatain Tourism 2007; 15(3): 309-23.

[10] Rogers CS. Damage to coral reefs in Virgin Islands, National Park and Biosphere Reserve from Recreational Activities, Proceedings of 6th International Coral Reef Symposium 1988; vol. 2: pp. 40510 .

[11] Ammar MSA. Effect of recreational diving activities on Hurghada and Safaga coral reefs, In: International Conference on: Environmental Protection is a Must, May 5 - May 7, 1998, National Institute of of Oceanography and Fisheries (N.I.O.F), Euro-Arab Cooperation Center (V.E.A.), International Scientists Association (ISA) and Social Fund for Development (SFD) 1998; pp. 427-39.

[12] Wielgus J, Chadwick-Furman NE, Dubinsky Z. Coral cover and partial mortality on anthropogenically impacted coral reefs at Eilat, northern Red Sea. Marine Pollut Bull 2004; 48: 248-53.

[13] Rogers CS. Responses of coral reefs and reef organisms to sedimentation. Marine Ecol Progress Ser 1990; 62: 185-202. 
[14] Fricke HW, Schuhmacher H. The depth limits of Red Sea stony corals, an ecophysiological problem (A deep diving survey by submersible). PSZNI Mar Ecol 1983; 4 (2): 163-94.

[15] Todd PA, Siddle RC, Lewin-Koh NJI. An aquarium experiment for identifying the physical factors inducing morphological change in two massive scleractinian corals. J Exp Mar Biol Ecol 2004; 299: 97-113.

[16] Ammar MSA. Recovery patterns of corals at Shabrour Umm Gam'ar, Hurghada, Red Sea, Egypt, after the 1998 outbreak of Acanthaster planci. Zool Middle East 2007; 40: 97-104.

[17] Benayahu Y. Faunistic composition and patterns in the distribution of soft corals (Octocorallia Alcyonacea) along the coral reefs of $\mathrm{Si}$ nai Peninsula. Proceeding of the Fifth International Coral Reef Congress, Tahiti 1985; vol. 6: pp. 255-60.

[18] Pearson RG. Recovery and colonization of coral reefs. Mar Ecol Progress Ser 1981; 4: 105-22.

[19] Sheppard CRC. Reefs and coral assemblages of Saudi Arabia 2. Fringing Reefs in the Southern region. Jeddah Jizan Fauna Saudi Arabia 1985; 7: 37-58.

[20] Ammar MSA. Zonation of coral communities and environmental sensitivity offshore a resort site at Marsa Alam, Red Sea, Egypt. Egypt J Zool 2004; 42: 67-81.

[21] Atrigenio MP, Alino PM. Effects of the soft coral Xenia puertogalerae on the recruitment of scleractinian corals. J Exp Mar Biol Ecol 1996; 203(2): 179-89.

[22] Heanmailto RL, Cacho OJ. A growth model for giant clams Tridacna crocea and T. derasa. Ecol Modell 2003; 163 (1-2): 87-100.

[23] Hart AM, Bell JD, Foyle TP. Growth and survival of the giant clams, Tridacna derasa, T. maxima and T. crocea, at village farms in the Solomon Islands. Aquaculture 1998; 165 (3-4): 203-20.

[24] Barbeau MA, Durelle K, Aiken RB. A design for multifactorial choice experiments: an example using microhabitat selection by sea slugs Onchidoris bilamellata. J Exp Mar Biol Ecol 2004; 307(1): 116.

[25] Carpenter RC. Grazing by Diadema antillarum Phillippi and its effects on the benthic algal community. J Mar Res 1981; 39: 74765.

[26] Carpenter RC. Partitioning herbivory and its effects on coral reef algal communities. Ecol Monogr 1986; 56: 345-63.

[27] Ammar MSA. An alarming threat to the Red organ pipe coral Tubipora musica and suggested solutions. Ecol Res 2005; 20: 52935 .
[28] Jameson SC, Ammar MSA, Saadalla E, Mostafa HM, Riegl B. A coral damage index and its application to diving sites in the Egyptian Red Sea, Coral Reefs, Special Issue on The Science of Coral Reef Management 1999; 18 (4): 333-339.

[29] Hodgson G, Carpenter K. Scleractinian corals of Kuwait. Pacific Sci 1995; 49 (3): 207-26.

[30] Nzali LM, Johnstone RW, Mgaya YD. Factors affecting scleractinian coral recruitment on a nearshore reef in Tanzania. Ambio 1998; 27(8): 717-22.

[31] Hawkins JP, Roberts CM. Estimating the carrying capacity of coral reefs for scuba diving. In: Proceedings of the 8th International Coral Reef Symposium Panama 1997; vol. 2: pp. 1923-1926.

[32] Hawkins JP, Roberts CM. Effects of recreational SCUBA diving on fore-reef slope communities. Biol Conserv 1992; 62: 171-8.

[33] Kay AM, Liddle MJ. Impact of human trampling in different zones of a coral reef flat. Environ Manage 1989; 4: 509-20.

[34] Neil D. Potential of corals stress due to sediment resuspension and deposition by reef walkers. Biol Conserv 1990; 52: 221-7.

[35] Ammar MSA. Improvement of the molecular and physiological behavior of the reef coral Stylophora pistillata at Hurghada, Red Sea, Egypt by using the ARCON substrate. J Egypt Acad Soc Environ Dev 2001; 2(2): 205-19.

[36] Ammar MSA, Mahmoud MA. A new innovated and cheep model in building artificial reefs. Egtian J Aquatic Res 2005; 31(1): 10518 .

[37] Baine M. Artificial reefs: a review of their design, application, management and performance. Ocean Coast Manage 2001; 44: 241-59.

[38] Ditton RB, Osburn HR, Baker TL, Thailing CE. Demographics, attitudes, and reef management preferences of sport divers in offshore Texas waters. ICES J Mar Sci 2002; 59: S186-91.

[39] Pears R, Williams DMcB. Potential effects of artificial reefs on the GREAT BARRIER reef. Cooperative Research Centre for the great barrier Reef World Heritage Area technical report 60, Townsville: James Cook University 2005.

[40] Sutton SG, Bushnell SL. Socio-economic aspects of artificial reefs: Considerations for the Great Barrier Reef Marine Park. Ocean Coast Manage 2007; 50: 829-46.

[41] Elliott M, Burdon D, Hemingway KL, Apitz SE. Estuarine, coastal and marine ecosystem restoration: Confusing management and science - A revision of concepts. Estuar Coast Shelf Sci 2007; 74: $349-66$. 